\title{
ON A ROAD TO NOWHERE: IMPLIED DECLARATIONS OF INCONSISTENCY AND THE NEW ZEALAND BILL OF RIGHTS ACT
}

\author{
Claudia Geiringer ${ }^{*}$
}

This article explores recent case law touching on the suggestion that the New Zealand courts have an implied power to formally declare that legislation is inconsistent with the rights and freedoms contained in the New Zealand Bill of Rights Act 1990. The article concludes from this case law that the prospects for the development of a formal declaratory jurisdiction of this kind in New Zealand are, if anything, receding. Further, although the Supreme Court's decision in R v Hansen [2007] 3 NZLR 1 affirms the power of the New Zealand courts to informally "indicate" the existence of such legislative inconsistencies, early indications suggest that it is unlikely that this power will be exercised on a routine basis. In the absence of legislative reform, any "dialogue" over human rights between the New Zealand courts and the political branches of government is likely to continue to be far more sporadic and sotto voce than in those countries that have legislated for an express declaration of inconsistency power.

\section{INTRODUCTION}

As is well known, the New Zealand Bill of Rights Act 1990 (the NZ Bill of Rights) does not empower the judiciary to enforce the rights contained in it against the legislature. Section 6 of the NZ Bill of Rights directs those charged with the interpretation of enactments to prefer a rights-

* Senior Lecturer, Victoria University of Wellington Faculty of Law. This is a revised version of a paper prepared for and presented at the conference "Celebrating 60 years of the Universal Declaration of Human Rights" (Victoria University of Wellington, Wellington, 9 and 10 December 2008) and to be published in the conference proceedings. My thanks to Lani Inverarity for her research assistance and to the anonymous VUWLR reviewer. My gratitude also goes to Joanna Davidson, Professor David Feldman, Professor ATH Smith and Renuka Thilagaratnam for assistance with the comparative context. 
consistent meaning wherever one is available. ${ }^{1}$ Where one is not available, however, section 4 forbids the courts from striking down or refusing to apply legislation.

New Zealand's failure to enshrine core human rights within an entrenched, supreme law document has rendered it something of an outrider in international terms and has attracted criticism at an international level. ${ }^{2}$ During the last ten years, however, three common law jurisdictions - the United Kingdom, the Australian Capital Territory (the ACT) and the State of Victoria - have followed New Zealand in adopting similar statutory human rights charters. The burgeoning of such instruments has been accompanied by a wave of scholarly literature that portrays their use as an innovative constitutional development in its own right, rather than a second-best option necessitated by a failure to achieve the necessary consensus to support more fundamental constitutional change. ${ }^{3}$ One significant strand within this literature deploys the term "dialogue" to describe the shared responsibilities of judges and politicians under this new wave of human rights instruments. ${ }^{4}$ The suggestion is that these instruments herald a "new constitutionalism" that deepens the "complex,

1 More precisely, s 6 of the New Zealand Bill of Rights Act 1990 [the NZ Bill of Rights] says: "Wherever an enactment can be given a meaning that is consistent with the rights and freedoms contained in this Bill of Rights, that meaning shall be preferred to any other meaning." The limits of rights-consistent meaning under $\mathrm{s} 6$ were explored by the Supreme Court of New Zealand in $R v$ Hansen [2007] 3 NZLR 1 (NZSC). See Claudia Geiringer "The Principle of Legality and the Bill of Rights Act: A Critical Examination of $R v$ Hansen" (2008) 6 NZJPIL 59 ["The Principle of Legality"]; also published in Claudia Geiringer and Dean R Knight (eds) Seeing the World Whole: Essays in Honour of Sir Kenneth Keith (Victoria University Press, Wellington, 2008) 69.

2 See UN Human Rights Committee "Concluding Observations of the Human Rights Committee: New Zealand" (3 October 1995) CCPR/C/79/Add.47, paras 176 \& 185; UN Human Rights Committee "Concluding Observations of the Human Rights Committee: New Zealand" (7 August 2002) CCPR/CO/75/NZL, para 8. For a particularly nuanced response to the Human Rights Committee see Janet McLean "Legislative Invalidation, Human Rights Protection and s 4 of the New Zealand Bill of Rights Act" [2001] NZ Law Rev 421.

3 For example McLean, above n 2; Anthony Lester "The Magnetism of the Human Rights Act 1998" (2002) 33 VUWLR 53; F Klug "The Human Rights Act - A 'Third Way' or a 'Third Wave' Bill of Rights" [2001] EHRLR 361; Philip A Joseph "Parliament, the Courts, and the Collaborative Enterprise" (2004) 15 KCLJ 321, especially 344 ["The Collaborative Enterprise"]; Janet L Hiebert "Interpreting a Bill of Rights: The Importance of Legislative Rights Review" (2005) 35 BJ Pol S 235; George Williams "The Victorian Charter of Human Rights and Responsibilities: Origins and Scope" (2006) 30 Melb U LR 880; Roger Masterman "Interpretations, Declarations and Dialogue: Rights Protection under the Human Rights Act and Victorian Charter of Human Rights and Responsibilities" [2009] PL 112.

4 See for example Klug, above n 3, 370; Tom R Hickman "Constitutional Dialogue, Constitutional Theories and the Human Rights Act 1998" [2005] PL 306; Williams, above n 3, 901-903. In New Zealand, see Philip A Joseph "The Higher Judiciary and the Constitution: A View from Below" in Rick Bigwood (ed) Public Interest Litigation: New Zealand Experience in International Perspective (LexisNexis, Wellington, 2006) 213, 229-233 ["The Higher Judiciary and the Constitution"]. The dialogue metaphor is borrowed most directly from Canadian discourse over Charter rights: see most especially Peter W Hogg and Allison A Bushell "The Charter Dialogue Between Courts and Legislatures (Or Perhaps the Charter of Rights Isn't Such a Bad Thing After All)" (1997) 35 Osgoode Hall LJ 75. 
reciprocal linkages" between the different branches of government when engaging in the shared enterprise of human rights protection. ${ }^{5}$

For those who know anything of the periodic excesses of judicial supremacy under the grandparent of supreme law bills of rights in the United States, the idea of a "dialogical" human rights charter cannot help but be of at least passing attraction. If the effectiveness of the NZ Bill of Rights as a conduit for such "dialogue" is, however, to be assessed, attention must inevitably be brought to bear on a key lacuna in the design of the New Zealand instrument. All three of the jurisdictions that have to date followed New Zealand in adopting statutory charters of rights have incorporated within their instruments an express power for certain courts, in certain circumstances, to make formal (albeit unenforceable) declarations of legislative inconsistency with fundamental rights, and much of the dialogue over "dialogue" in these jurisdictions has focussed on this constitutional innovation. ${ }^{6}$ On its face, the New Zealand instrument contains no such equivalent. In this sense, New Zealand's constitutional arrangements for the protection of human rights are now out of step, not only with the vast majority of states that have adopted fully constitutionalised bills of rights, but also with the small but growing number of states that have followed New Zealand's example in adopting statutory versions.

What, though, of the suggestion that even in the absence of an express power, the New Zealand courts nevertheless have a jurisdiction to make declarations of legislative inconsistency with the NZ Bill of Rights? Almost since the inception of the NZ Bill of Rights, some commentators and some judges have speculated about the existence of such an implied power, although no declaration has ever been made. ${ }^{7}$ Does such a jurisdiction exist and, if so, to what extent does it compensate for the absence of an express power? Can we, too, claim to have a "dialogical" bill of rights?

In recent years, there has been a marked increase in the number of cases coming before the courts in which counsel have sought declarations of legislative inconsistency with the NZ Bill of Rights. This article considers the implications of the recent case law for the questions just identified. The starting point in identifying those implications is the Supreme Court decision in $R v$ Hansen, which confirms emphatically that the New Zealand courts are entitled to inquire into the conformity of legislation with the standards contained in the NZ Bill of Rights and to document their conclusions in their judgments. ${ }^{8}$ There is, however, a separate question as to whether the courts are

5 See Joseph "The Collaborative Enterprise", above n 3, 344.

6 For example Williams, above n 3, 902-905; Masterman, above n 3, 121-125.

$7 \quad$ See for example F M Brookfield "Constitutional Law" [1992] NZ Recent Law 231, 239; Philip A Joseph "The New Zealand Bill of Rights" (1996) 7 PLR 162, 167; Quilter v Attorney-General [1998] 1 NZLR 523, 554 (CA) Thomas J [Quilter]; Paul Rishworth "Reflections on the Bill of Rights after Quilter v AttorneyGeneral" [1998] NZ Law Rev 683, 689-695.

8 Hansen, above n 1. 
entitled to grant formal declaratory relief. This article concludes that the prospects for such a remedial jurisdiction are, if anything, receding. Recent case law purports to narrow considerably the scope of such a jurisdiction, if indeed it exists at all. Further, the tenor of this body of case law suggests that, even if a residual jurisdiction to make declarations of inconsistency is eventually recognised, it will be exercised only rarely.

If Hansen has established that the courts may inquire into and identify examples of legislative inconsistency with the NZ Bill of Rights, what does it matter if they do not grant (non-binding) declaratory relief? This article addresses some of the potential advantages of regularising the grant of formal relief. The key point that is made, however, is that it is a mistake to assume that following Hansen, the courts will informally indicate legislative inconsistency with the NZ Bill of Rights in anything like the same range of circumstances as might have attracted a declaration of inconsistency were there an express jurisdiction to grant such relief. For reasons that are explored in the article, early indications from the post-Hansen case law are that Hansen-style informal "indications" of legislative inconsistency with the NZ Bill of Rights will be far from routine.

In short, it is suggested that in the absence of an express remedial jurisdiction to make nonbinding declarations of legislative inconsistency with the NZ Bill of Rights, the New Zealand courts' participation in any "dialogue" with the political branches of government is likely to continue to be far more tentative and self-effacing than in those jurisdictions that have adopted express declaration of inconsistency powers. Whether or not this is desirable as a matter of policy is a question that is left to be addressed elsewhere.

\section{SOME NECESSARY BACKGROUND}

Before focusing on the recent case law, it is helpful to begin with a brief survey of the declaration of inconsistency debate during the first decade-and-a-half following the enactment of the NZ Bill of Rights. The idea that the New Zealand instrument might (impliedly) confer a power on the courts to declare legislation inconsistent with the rights contained in it was first put forward by Professor F M Brookfield in 1992. ${ }^{9}$ There was some early judicial and scholarly interest in Professor Brookfield's suggestion, ${ }^{10}$ but it was not until the Court of Appeal issued its decision in Moonen v Film and Literature Board of Review (Moonen) that the New Zealand debate over an implied declaration of inconsistency power really got under way. ${ }^{11}$

In order to make sense of Moonen and the declaration of inconsistency debate more generally, it is necessary to delve further into the operative provisions of the NZ Bill of Rights. Section 6 Rights", above n 7, 167.

11 Moonen v Film and Literature Board of Review [2000] 2 NZLR 9 (CA) [Moonen]. 
(requiring right-consistent interpretations where possible) and section 4 (preventing the courts from striking down legislation) have already been adverted to. ${ }^{12}$ Key, also, to the debate is section 5 , which provides:

5. Justified limitations - Subject to section 4 of this Bill of Rights, the rights and freedoms contained in this Bill of Rights may be subject only to such reasonable limits prescribed by law as can be demonstrably justified in a free and democratic society.

Throughout much of the history of the NZ Bill of Rights, there has been considerable uncertainty as to the role of this section and as to its relationship with the other operative provisions. ${ }^{13}$ The significance of Moonen was that it offered a view from a unanimous bench of five members of the Court of Appeal on those issues. Tipping $J$ for the Court set out a series of steps that might assist in cases involving the interpretation and application of primary legislation where a possible inconsistency with the NZ Bill of Rights had been identified. ${ }^{14}$ First, he suggested, one should identify all of the tenable meanings of the relevant legislation. Then, one should adopt the one that constitutes the least possible limitation on the right in question. ${ }^{15}$ These two steps will be sufficient to resolve the dispute between the parties - a "meaning" will have been attributed to the legislation and, by virtue of section 4, the legislation as so interpreted must be applied. Nevertheless, Tipping $\mathrm{J}$ suggested that one should then proceed to consider whether or not the meaning that is to be adopted constitutes a justified limit on the relevant right or freedom in terms of section $5 .{ }^{16}$ If the limit on the right is not justified, Tipping $\mathrm{J}$ said, the Court may "indicate" or "declare" that to be so. Tipping $\mathrm{J}$ recognised that because of section 4, this is a somewhat academic exercise. Nevertheless, he suggested: ${ }^{17}$

[The] purpose [of section 5] necessarily involves the Court having the power, and on occasions the duty, to indicate that although a statutory provision must be enforced according to its proper meaning, it is inconsistent with the Bill of Rights, in that it constitutes an unreasonable limitation on the relevant right or freedom which cannot be demonstrably justified in a free and democratic society. Such judicial indication will be of value should the matter come to be examined by the [United Nations] Human Rights Committee. It may also be of assistance to Parliament if the subject arises in that forum. In the

12 See Part I Introduction.

13 For an early illustration of the contrasting approaches see Ministry of Transport $v$ Noort; Police v Curran [1992] 3 NZLR 260, 271-273 (CA) Cooke P [Noort]; ibid, 277-278 \& 283-284 Richardson J; ibid, 287 Hardie Boys J; ibid, 295-296 Gault J.

14 Moonen, above n 11, paras 17-19.

15 Ibid, para 17.

16 Ibid, paras 18-19.

17 Ibid, para 20. See also Quilter, above n 7, 554 Thomas J, noting that "it would be a serious error not to proclaim a violation [of the NZ Bill of Rights] if and when a violation is found to exist in the law". 
light of the presence of s 5 in the Bill of Rights, New Zealand society as a whole can rightly expect that on appropriate occasions the Courts will indicate whether a particular legislative provision is or is not justified thereunder.

In considering the significance of Moonen, it is helpful to identify two distinct but related questions buried within the declaration of inconsistency debate: a substantive question and a remedial question. The substantive question is whether (and if so, when and how) the courts are empowered to enter into a section 5 inquiry and, thus, to pronounce on the justifiability of legislation that encroaches on the rights and freedoms protected by the NZ Bill of Rights. The remedial question is whether (and if so in what circumstances) the courts are empowered to issue a formal declaration to that effect.

Moonen offered an affirmative answer to the first question - the courts can and should inquire into the justifiability of legislative breaches of the Bill of Rights. Moonen's answer to the remedial question is, however, open to different interpretations. Some commentators and at least one judge have read Moonen as affirming a jurisdiction to make formal declarations of legislative inconsistency with the NZ Bill of Rights along the lines envisaged by Professor Brookfield. ${ }^{18}$ They are, no doubt, encouraged in this view by the fact that, just a few months prior to the delivery of the Moonen decision, the United Kingdom Parliament had enacted the Human Rights Act 1998 (UK) (the UK Human Rights Act), which empowers the superior courts to issue formal declarations of legislative "incompatibility" with the rights found in the European Convention on Human Rights. ${ }^{19}$ In the face of such a declaration the legislation survives, though the UK Human Rights Act confers on the government of the day a power (but not an obligation) to make a remedial order addressing the violation. ${ }^{20}$

It is perhaps not unreasonable to assume that this United Kingdom constitutional reform was not far from the mind of Tipping J when he wrote the Moonen decision. Nevertheless, on the question of whether the courts can issue formal declarations of legislative inconsistency with the NZ Bill of Rights, Moonen is ambiguous at best. At one point in the judgment, Tipping $\mathrm{J}$ does state that if there is a legislative inconsistency with section 5 , the courts may "declare this to be so". ${ }^{21}$ But in context,

18 For example Paul Rishworth "Human Rights" [1999] NZ Law Rev 457, 468-469 ["Human Rights"]; Joseph "The Higher Judiciary and the Constitution", above n 4, 229; Michael Taggart "Commentary: 'Dialogue' as Inter-Branch Communication" in Geiringer and Knight (eds), above n 1, 340, 344; Zaoui v AttorneyGeneral [2004] 2 NZLR 339, para 166 (HC) [Zaoui (HC Williams J)].

19 Human Rights Act 1998 (UK), s 4.

20 Human Rights Act 1998 (UK), ss 4(6) \& 10, and sch 2. Though there is no domestic legal obligation to make such a remedial order, the United Kingdom government's power to refuse to do so is, in practical terms, constrained by the binding (at international law) powers of the European Court of Human Rights to require redress for violations of the European Convention of Human Rights.

21 Moonen, above n 11, para 19. 
it is by no means clear that he uses the word "declare" in its formal sense rather than simply as a synonym for "state" or "assert". His preferred language, used three times in the judgment, is "indicate". ${ }^{22}$ He may, therefore, simply have meant that the Court should identify legislative inconsistency as part of its reasoning process. ${ }^{23}$

The difference between these two alternatives was further highlighted in $R v$ Poumako, issued only a few months after Moonen. ${ }^{24}$ In Poumako, all five members of the Court of Appeal considered that there had been a serious and unjustifiable legislative breach of section 25(g) of the NZ Bill of Rights (protecting against the retrospective imposition of a penalty) and urged Parliament to redress the breach. The majority of members of the Court of Appeal nevertheless avoided answering the question whether formal declaratory relief was available by finding that the offending law had not materially affected the position of the appellant. ${ }^{25}$ Thomas $\mathrm{J}$ alone would have made a formal declaration. ${ }^{26}$

The Moonen and Poumako decisions, coupled with the United Kingdom constitutional reform, triggered a raft of academic comment, ${ }^{27}$ but further judicial clarification has not been forthcoming. Almost a decade following Moonen, the only judge other than Thomas $\mathrm{J}$ in Poumako to have affirmed the existence of such a remedial jurisdiction is Williams $\mathrm{J}$ in the High Court in Zaoui $v$ Attorney-General. ${ }^{28}$ His view was that Moonen and Poumako had clearly established a jurisdiction to make declarations of inconsistency. Nevertheless, he expressed considerable reservations about the exercise of that jurisdiction and preferred to resolve the case before him without resort to it. ${ }^{29}$

22 Ibid, paras 19-20.

23 This is the reading recently given to Moonen by the Court of Appeal in Boscawen v Attorney-General [2009] 2 NZLR 229, para 52 (CA) O'Regan J for the Court [Boscawen (CA)]. See also Andrew Butler and Petra Butler The New Zealand Bill of Rights Act: A Commentary (LexisNexis, Wellington, 2005) 1024

$24 \quad R$ v Poumako [2000] 2 NZLR 695 (CA).

25 Ibid, paras 42-43 Gault J for Richardson P, and Gault and Keith JJ; ibid, paras 67-68 Henry J.

26 Ibid, paras 86-107 Thomas J.

27 See for example Andrew Butler "Judicial Indications of Inconsistency - A New Weapon in the Bill of Rights Armoury?" [2000] NZ Law Rev 43; Rishworth "Human Rights", above n 18, 468-469; Philip A Joseph "Constitutional Law" [2000] NZ Law Rev 301, 318-319; James Allan "Moonen and McSense" [2002] NZLJ 142.

28 Zaoui (HC Williams J), above n 18. Between 2000 and 2005, further limited (and inconclusive) judicial discussion of the declaration of inconsistency question can be found in the following cases: ER v FR [2004] NZFLR 633, para 30 (CA) William Young J for the Court; Hopkinson v Police [2004] 3 NZLR 704, para 83 (HC); Zaoui v Attorney-General (16 July 2004) HC AK CIV2004-404-2309, para 85; Reid v Minister of Labour [2005] NZAR 125, para 19 (HC); Zaoui v Attorney-General [2005] 1 NZLR 577, para 108 (CA) McGrath J; $R$ v Te Kahu [2006] 1 NZLR 459, paras 44-45 (CA) William Young J for the Court.

29 Zaoui (HC Williams J), above n 18, paras 166-167. 
In the last three years, however, there has been a marked increase in the number of cases to come before the New Zealand courts in which counsel have sought declarations of legislative inconsistency with the NZ Bill of Rights. As a result, a significant (though inconclusive) body of case law has been generated. ${ }^{30}$ Before considering the implications of this new body of case law, two other aspects of the wider context should be noted. First, in 2001, in a somewhat constitutionally incongruous move, the New Zealand Parliament amended the Human Rights Act 1993 (the NZ Human Rights Act) and vested in the Human Rights Review Tribunal an express power to formally declare legislation to be inconsistent specifically with section 19 of the NZ Bill of Rights: the right to be free from discrimination. ${ }^{31}$ This is an important and, as yet, understudied jurisdiction but space constraints do not enable its implications to be pursued directly in this article. ${ }^{32}$ The important point for the purposes of this discussion is that its substantive reach is narrow and so it does not compensate for the absence of a more general power within the NZ Bill of Rights itself.

Secondly, the ACT and the State of Victoria in Australia have each now adopted statutory charters of rights and have followed the United Kingdom by including in each of them a declaration of inconsistency power. ${ }^{33}$

\section{IMPLICATIONS OF THE NEW CASE LAW}

What, then, are the implications of this new body of case law for the recognition of a declaration of inconsistency jurisdiction under the NZ Bill of Rights? In order to address this issue, it is helpful to return to the two questions previously identified: the substantive question (whether the courts can inquire into the conformity of legislation with the standards contained in the NZ Bill of Rights) and the remedial question (whether there is a jurisdiction to grant formal declaratory relief).

30 In the three years between July 2006 and June 2009, for example, the Court of Appeal and/or the Supreme Court touched on the declaration of inconsistency question in nine separate cases: see Taunoa $v$ AttorneyGeneral [2006] NZSC 95 [Taunoa (NZSC Decision on Stay)]; Hansen, above n 1; R v Manawatu (2006) 23 CRNZ 833 (CA) [Manawatu (CA)]; Christopher John Manawatu v R [2007] NZSC 13 [Manawatu (NZSC)]; Belcher v Chief Executive of the Department of Corrections [2007] 1 NZLR 507 (CA) [Belcher (CA 1)]; Belcher v Chief Executive of the Department of Corrections [2007] NZCA 174 [Belcher (CA 2)]; Belcher $v$ Chief Executive of the Department of Corrections [2007] NZSC 54 [Belcher (NZSC)]; $R v$ Exley [2007] NZCA 393 [Exley (CA)]; $R v$ McMillan [2007] NZCA 394; $R v$ Chatha (No 2) [2008] NZCA 466 [Chatha (CA)]; Boscawen (CA), above n 23; Wenzel v $R$ [2009] NZSC 58.

31 Human Rights Act 1993, s 92J, read with Part 1A.

32 For an excellent recent discussion of this jurisdiction see Roydon Hindle "Rights Against Legislated Discrimination: A Sleeping Giant? Part 1A of the Human Rights Act 1993" [2008] NZ Law Rev 213.

33 Human Rights Act 2004 (ACT), s 32; Charter of Human Rights and Responsibilities Act 2006 (Victoria), s 36. The power is termed a "declaration of inconsistent interpretation" in the Victorian Act and a "declaration of incompatibility" in the ACT Act. 


\section{A Substantive Jurisdiction Definitively Established}

The recent case law offers a definitive (and affirmative) answer to the substantive question. The courts are entitled to inquire into legislative consistency with the NZ Bill of Rights, including by reference to the standard of justifiability found in section 5 , and to record their conclusions in their decisions. $^{34}$

Of course, the Moonen Court had already accepted this proposition, but it will be remembered that Tipping $\mathrm{J}$ in Moonen saw section 5 as having a residual role. First, one resolves the question of statutory interpretation using sections 4 and 6 of the NZ Bill of Rights. Only once that is done does one engage in a hypothetical inquiry into whether any resulting limit that is placed on a right or freedom is justified in terms of section 5 of the NZ Bill of Rights. ${ }^{35}$ This means that the section 5 inquiry is tacked onto the end of the analysis and divorced from the actual disposition of the case. Perhaps for that reason, there are few examples of judges actually applying the Moonen methodology and conducting a section 5 inquiry into the justifiability of legislative breaches of the NZ Bill of Rights.

In contrast, in $R v$ Hansen, a majority of the Supreme Court took a more integrated view of the relationship between sections 5 and 6 of the NZ Bill of Rights. In its view, section 5 of the NZ Bill of Rights acts as an implicit qualification to the interpretive direction in section 6 of the NZ Bill of Rights. Section 6 does not require the interpreter to adopt the meaning that is most consistent with the rights and freedoms contained in the NZ Bill of Rights but, rather, to adopt an interpretation that does not limit rights in an unjustified manner. On this approach, a section 5 inquiry is a necessary precursor to a section 6 inquiry. One first asks whether the "ordinary" (non-NZ Bill of Rightsinfluenced) meaning of the legislation would limit a right or freedom in a manner that cannot be justified in terms of section 5 . If the answer is "no", then the ordinary meaning must be applied. It is only if the answer is "yes" that the interpreter must proceed to consider whether, in light of section 6 of the NZ Bill of Rights, an alternative, rights-consistent meaning is available. ${ }^{36}$

The Hansen methodology, therefore, seeks to imbed the section 5 inquiry into the very process by which courts interpret and apply legislation and, thus, dispose of the rights and duties of the parties before them. If applied faithfully, no court or tribunal would be able to dispose of a case involving an issue of statutory interpretation without having identified any prima facie legislative breach of the rights and freedoms contained in the NZ Bill of Rights and reached a view as to

34 Hansen, above $\mathrm{n} 1$.

35 Moonen, above n 11, paras 17-19.

36 Hansen, above n 1, paras 57-62 Blanchard J; ibid, paras 89-94 Tipping J; ibid, paras 186-192 McGrath J. Compare ibid, paras 6 and 15-24 Elias CJ. 
whether that breach is, or is not, justifiable. ${ }^{37}$ In expanding on this aspect of the proposed methodology, McGrath J noted as follows: ${ }^{38}$

... a New Zealand court must never shirk its responsibility to indicate, in any case where it concludes that the measure being considered is inconsistent with protected rights, that it has inquired into the possibility of there being an available rights consistent interpretation, that none could be found, and that it has been necessary for the court to revert to s 4 of the Bill of Rights Act and uphold the ordinary meaning of the other statute. Normally that will be sufficiently apparent from the court's statement of its reasoning.

Articulating the reasoning serves the important function of bringing to the attention of the executive branch of government that the court is of the view that there is a measure on the statute book which infringes protected rights and freedoms, which the court has decided is not a justified limitation. It is then for the other branches of government to consider how to respond to the court's finding. While they are under no obligation to change the law and remedy the inconsistency, it is a reasonable constitutional expectation that there will be a reappraisal of the objectives of the particular measure, and of the means by which they were implemented in the legislation, in light of the finding of inconsistency with these fundamental rights and freedoms concerning which there is general consensus in New Zealand society and there are international obligations to affirm.

Similarly, Anderson J observed that the Court's opinion as to the consistency of the legislation with the NZ Bill of Rights will have a "social value in bringing to notice an enactment which is inconsistent with fundamental rights and freedoms" and that Parliament, in enacting the NZ Bill of Rights, had "accepted the prospect" of such judicial assessments. ${ }^{39}$

Hansen, then, affirms the proposition laid down in Moonen that courts are entitled to review legislation against the standards found in the NZ Bill of Rights, and to record their conclusions in their decisions. Further, the integrated approach taken to sections 5 and 6 in Hansen ought, in theory, to make it more difficult for courts and tribunals to avoid undertaking a section 5 inquiry into the justifiability of legislative breaches of the NZ Bill of Rights in cases involving questions of statutory interpretation. One limitation inherent in the Hansen approach, however, needs to be borne in mind. Under it (arguably, unlike Moonen) the dictates of statutory interpretation have become the

37 Whereas this will generally involve a s 5 analysis, the Supreme Court has indicated that there are some rights in respect of which no breach can ever be justified under s 5. Section 21 (unreasonable search or seizure) is an example: see Cropp v Judicial Committee [2008] 3 NZLR 774, para 33 (NZSC) Blanchard J for the Court. See Claudia Geiringer "Shaping the Interpretation of Statutes: Where are we now in the s 6 debate?" in New Zealand Law Society Using the Bill of Rights in Civil and Criminal Litigation (NZLS Continuing Legal Education, Wellington, 2008) 1, 9 for discussion of the suggestion that Hansen does not apply in cases involving a "continuum" of possible meaning.

38 Hansen, above n 1, paras 253-254.

Ibid, para 267. 
primary rationale for entering into an examination of legislative consistency with the NZ Bill of Rights. This means that, on one view, an assessment of legislative consistency may be unnecessary in cases that do not raise a bona fide interpretation issue. ${ }^{40}$ The effect of this in practice is explored below. ${ }^{41}$

\section{B Poor Prospects for a Formal Remedial Jurisdiction}

In contrast, the recent case law indicates that prospects for a formal remedial jurisdiction are poor. Although all of the cases continue to leave open the ultimate question as to whether there is such a jurisdiction, a number of them place significant hedges around its scope and the circumstances in which it might be exercised, the most significant being its restriction to civil proceedings. More generally, the tenor of this body of case law suggests that, even if a residual jurisdiction to make declarations of inconsistency does exist, it will be exercised only rarely.

1 The "subject matter" must have been raised before the court of first instance

This proposition derives from the Supreme Court's decision in Taunoa v Attorney-General (Taunoa), though its width is somewhat unclear. ${ }^{42}$

The Taunoa plaintiffs had successfully sued the Attorney-General in the High Court for damages for various breaches of the NZ Bill of Rights relating to their confinement at Auckland prison. ${ }^{43}$ The parties to the Taunoa proceedings appealed and cross-appealed to the Court of Appeal and, in due course, to the Supreme Court. ${ }^{44}$ In the meantime, as part of the political fallout from the High Court decision in Taunoa, the Government enacted the Prisoners' and Victims' Claims Act 2005 (the PVC Act). Its effect on the Taunoa plaintiffs was that any damages eventually awarded to them following the final resolution of the proceedings would be held by the Secretary of Justice for a specified period to enable the victims of the plaintiffs' crimes to make claims against the amount.

When Taunoa came to the Supreme Court, the plaintiffs made an interlocutory application to stay or strike out the Attorney-General's cross-appeal. As part of that application, they sought a declaration that the PVC Act was inconsistent with the NZ Bill of Rights. The Supreme Court dismissed the application, holding that a declaration of inconsistency was plainly beyond the jurisdiction of the Supreme Court in the circumstances of the appeal. This was because the "subject

40 See Exley (CA), above n 30, para 20; Exley $v$ R [2007] NZSC 104, para 2 [Exley (NZSC)].

41 Part IV What Difference Would it Make?

42 Taunoa (NZSC Decision on Stay), above $\mathrm{n} 30$.

43 Taunoa v Attorney-General (2004) 7 HRNZ 379 (HC); Taunoa v Attorney-General (2004) 8 HRNZ 53 (HC).

44 Attorney-General v Taunoa [2006] 2 NZLR 457 (CA); Taunoa v Attorney-General [2006] NZSC 30; Taunoa v Attorney-General [2008] 1 NZLR 429 (NZSC). 
matter" of the application had never been before the High Court (nor, indeed, the Court of Appeal). In effect, the plaintiffs were seeking to bring a new case directly to the Supreme Court, which does not have an originating jurisdiction. ${ }^{45}$

In Belcher v Chief Executive of the Department of Corrections (Belcher), the appellant sought a declaration from the Court of Appeal that the legislative regime in the Parole Act 2002 empowering the making of "extended supervision orders" in respect of certain offenders unjustifiably breached the NZ Bill of Rights. ${ }^{46}$ A unanimous bench of five judges interpreted the Supreme Court's ruling in Taunoa to mean that there is no jurisdiction to make a declaration of inconsistency unless the declaration has been sought from the court of first instance. ${ }^{47}$

Though the Supreme Court refused leave to appeal in Belcher, the three judges who heard the leave application took the opportunity to "correct" the Court of Appeal's "erroneous" interpretation of Taunoa. The Belcher Court had not, they said, been faced with the same jurisdictional difficulty as existed in Taunoa. That difficulty arose because the asserted cause of action "could not have existed when the proceeding was before the High Court since the Act of Parliament in respect of which relief was sought had not been enacted". ${ }^{48}$ In Belcher, by contrast, the issue (the application of the "extended supervision order" regime) was before the High Court. Accordingly, the grant of a declaration of inconsistency would not have amounted to the exercise of an originating jurisdiction. ${ }^{49}$

One can perhaps be forgiven for questioning whether the current law of New Zealand is represented by the unanimous decision of five members of the permanent Court of Appeal in Belcher or by the observation of three members of the Supreme Court in the same case in the course of declining the leave application. ${ }^{50}$ Assuming that we should allow ourselves to be guided by the latter, it seems that this particular jurisdictional difficulty will only exist where the request for a declaration of inconsistency relies on subject matter that is wholly unrelated to the case at first instance. ${ }^{51}$ In McDonnell $v$ Chief Executive of the Department of Corrections [McDonnell],

45 Taunoa (NZSC Decision on Stay), above n 30, paras 6-8.

46 Belcher (CA 1), above n 30; Belcher (CA 2), above n 30.

47 Ibid, para 11.

48 Belcher (NZSC), above n 30, para 7.

49 Ibid, para 8.

50 See Rt Hon Peter Blanchard "The Early Experience of the New Zealand Supreme Court" (2008) 6 NZJPIL 175, 193; also published in Geiringer and Knight (eds), above n 1, 321, noting that the status of leave decisions has not yet been determined.

51 In the United Kingdom context, the Court of Appeal for England and Wales has held that a Convention rights argument under the UK Human Rights Act is akin to a submission going to jurisdiction and can therefore be raised for the first time on appeal: B v Secretary of State for Work and Pensions [2005] 1 WLR 3796, para 17 (EWCA Civ) Sedley LJ. 
O'Regan $\mathrm{J}$ for a unanimous Court of Appeal summarised the position post-Taunoa/Belcher thus: "There is no jurisdictional bar to the Court of Appeal granting a declaration of inconsistency where such a declaration was not first sought in the High Court but was technically available." 52

The view expressed by the Supreme Court in Belcher acknowledges the reality that the constitutional issues at the heart of an assessment of legislative consistency with the NZ Bill of Rights will sometimes take time to crystallise and will not always be a focus for first instance trial advocates. However, the Supreme Court's view as to the absence of a jurisdictional bar on this basis may be of little practical effect. That is because it is clear from the subsequent case law that the Court of Appeal nevertheless considers that a failure to request a declaration at an early stage is likely to provide a discretionary basis for the refusal of relief. For example, in $R v$ Chatha (No 2) (Chatha), Glazebrook $\mathrm{J}$ gave, as one of the reasons for refusing a request for a declaration of inconsistency, the fact that the request had been made without warning in the course of the resumed hearing of the appeal, thus depriving the Court of the benefit of considered submissions or evidence from the Crown. ${ }^{53}$ In McDonnell (another case involving an application for an "extended supervision order"), Mr McDonnell's counsel had, in fact, indicated before the case came to a hearing in the High Court that he intended to seek a declaration of inconsistency. He was advised in a minute from Cooper $\mathrm{J}$ to pursue the issue through separate civil proceedings but did not do so. The day before the High Court hearing was to commence, counsel filed submissions seeking a "Hansen declaration" (ie, an informal indication of inconsistency). Baragwanath $\mathrm{J}$ did not entertain the submission, apparently because of the fact that the proceeding was a criminal matter. ${ }^{54}$ Then, in the notice of appeal to the Court of Appeal, counsel asserted that the High Court had made an error of law in declining to make a declaration of inconsistency.

The Court of Appeal felt that, despite this notice of appeal, the Crown had not been given adequate warning of the basis on which the appellant was applying for a declaration. It observed: 55

The first indication which the Court or the Chief Executive had of the basis for the argument that a declaration of inconsistency should have been made, or indeed that the remedy sought was a declaration rather than a statement of inconsistency of the kind made in Hansen, came when submissions were filed on behalf of the appellant on 20 February 2009 [three weeks before the hearing]... [T]his Court is now placed in substantially the same position as the Court found itself in the

52 McDonnell $v$ Chief Executive of the Department of Corrections [2009] NZCA 352, para 123(d) [McDonnell].

53 Chatha (CA), above n 30, para 32. See also Wenzel, above n 30, para 3.

54 See the discussion about lack of jurisdiction in criminal cases at Part III B 2 No jurisdiction to make declarations of inconsistency in criminal proceedings.

55 McDonnell, above n 52, paras 129-130 and, more generally, 124-131. 
Belcher litigation. It is being asked to deal with the issues arising from the declaration application without the benefit of a High Court decision.

The Court refused to entertain the request - either for a formal declaration or informal indication of inconsistency - in part, it seems, because of this perceived procedural failure. ${ }^{56}$ The judges in McDonnell were clearly concerned about the inadequacy of argument before them on the justifiability issue, the difficulties in having evidence adduced for the first time in the Court of Appeal and the fact that the Chief Executive of the Department of Corrections rather than the Attorney-General was the respondent. ${ }^{57}$

\section{No jurisdiction to make declarations of inconsistency in criminal proceedings}

The most significant hedge that has been placed around the declaration of inconsistency jurisdiction is that it is not available in criminal proceedings. In Belcher, a majority of four judges of the Court of Appeal (with the fifth, Hammond J, reserving his position) held that a declaration of inconsistency is a "civil remedy" that cannot be granted in a criminal proceeding. ${ }^{58}$ The Court of Appeal distinguished between the "criminal relief" given for breaches of the NZ Bill of Rights (for example, exclusion of evidence) and "truly civil relief" such as damages and, in its view, declarations. It gave a number of reasons for why declarations of inconsistency should not be available in criminal proceedings, which can be summarised as follows. ${ }^{59}$

- Criminal procedures are not appropriate for assessing "civil relief".

- There is a risk of the criminal process being diverted into collateral issues.

- The District Courts Act 1947 does not give District Court judges jurisdiction to make such declarations in civil proceedings, so there is no principled basis for them to have jurisdiction in criminal cases.

- If District Court judges do not have the jurisdiction in criminal cases, it would be anomalous for High Court judges to do so.

The width of the Belcher ruling no doubt requires clarification in future cases. It is clear that it captures questions that arise in the course of conviction and sentence. The "extended supervision order" regime at issue in Belcher itself is apparently also covered. What is less clear is whether the Belcher ruling captures, for example, extradition proceedings, proceeds of crime cases, habeas corpus applications and various types of contempt proceedings.

56 As explored below, the Court also applied the ruling in Belcher, above $\mathrm{n}$ 30, that an application for a declaration cannot be entertained in criminal proceedings.

57 McDonnell, above n 52, paras 129-131.

58 Belcher (CA 2), above n 30.

59 Ibid, paras 13-14. 
Whatever its precise width, it is a very significant limit indeed on the availability of declaratory relief. By far the majority of NZ Bill of Rights issues are raised in the context of criminal proceedings where the stakes are high, legal aid is more freely available and there is every incentive for those in jeopardy of criminal penalties to test the limits of the legal system. ${ }^{60}$ Further, criminal justice is an area of legislative policy where there is an ever-present risk of zealous legislative majorities seeking to push or indeed ignore the boundaries set by the contemporary human rights framework. The regime at issue in Belcher, for example, has attracted adverse reports under section 7 of the NZ Bill of Rights from both a Labour and a National Attorney-General. ${ }^{61}$

Presumably, the Belcher decision creates no jurisdictional bar to somebody in Mr Belcher's position initiating a subsequent civil challenge relating to the same subject matter (in the same way as one might bring a subsequent claim for Baigent damages). There may, however, be practical obstacles - most obviously financial - to bringing such claims. Additionally, a civil proceeding brought in such circumstances will probably have to take the form of a freestanding application for declaratory relief as any questions of statutory interpretation will have been resolved in the course of the prior criminal proceeding. As discussed below, the New Zealand courts may well be reluctant to acknowledge or exercise a declaratory jurisdiction in the case of freestanding applications of this kind. ${ }^{62}$ Finally, it is possible that the established principle that a civil court should only in exceptional circumstances give a declaratory judgment on an issue of criminal law may prove an additional obstacle in such a case. ${ }^{63}$

The Belcher ruling on the availability of declarations of inconsistency in criminal proceedings was directly relevant to the question before the Court and so cannot be considered obiter. It has subsequently been applied by the Court of Appeal in at least two further cases. ${ }^{64}$ Bearing that in

60 It is no coincidence that of the nine cases identified at above $n$ 30, seven would clearly be classed as criminal proceedings.

61 See "Report of the Attorney-General under the New Zealand Bill of Rights Act 1990 on the Parole (Extended Supervision) and Sentencing Amendment Bill" E63 www.parliament.nz (accessed 12 June 2009); "Report of the Attorney-General under the New Zealand Bill of Rights Act 1990 on the Parole (Extended Supervision Orders) Amendment Bill" J4 www.parliament.nz (accessed 15 July 2009).

62 Part III B 6 No freestanding application for a declaration. Though note that in McDonnell, above n 52, paras 124-126, the High Court appears to have encouraged Mr McDonnell to file separate civil proceedings that could then be dealt with concurrently with the criminal proceeding. It is perhaps unlikely that legal aid would have been available to Mr McDonnell to pursue that separate civil proceeding - a matter that does not seem to have been taken into account by any of the judges who considered the case.

63 Imperial Tobacco v Attorney-General [1981] AC 718 (HL). For an application of this principle to the UK Human Rights Act jurisdiction to make declarations of incompatibility see R(Rusbridger) $v$ AttorneyGeneral [2004] AC 357 (HL) [Rusbridger].

64 Exley (CA), above n 30; McMillan, above n 30. These cases were heard together: see ibid, para 14. See also McDonnell, above n 52, discussed further below, in which the Court of Appeal described the Belcher ruling as "obiter" but then proceeded to apply it. 
mind, the comments of a (differently constituted) bench of three judges of the Court of Appeal in Chatha are puzzling. ${ }^{65}$ In that case, Glazebrook J for a unanimous Court observed that it had "not been decided" whether such declarations are available, either in the civil or criminal context. ${ }^{66} \mathrm{Her}$ Honour cited the Supreme Court decision refusing leave to appeal in Belcher as authority for this proposition. ${ }^{67}$ The precedent value of such leave decisions has not yet been determined ${ }^{68}$ but, in any event, the Supreme Court passed no comment in its leave decision on the validity of the Court of Appeal's ruling that declarations of inconsistency are not available in criminal proceedings. Rather, the Supreme Court was content for the purposes of the leave application to "assum[e], without deciding" that a declaration of inconsistency is available in a criminal proceeding. ${ }^{69}$ It is true that the Supreme Court did, as discussed above, "correct" the Belcher Court's wide reading of the Taunoa judgment on the separate issue of whether the subject matter of the declaration must have been raised before the court of first instance. ${ }^{70}$ That, however, was a distinct question that only impacted peripherally at best on the question whether there is a jurisdiction to make declarations of inconsistency in criminal proceedings. ${ }^{71}$

Accordingly, the Court of Appeal's decision in Belcher stands until overruled - either by the Supreme Court or by the Court of Appeal itself. Given that leave to appeal on the jurisdiction question was refused in Belcher itself, the prospects for the former happening in the near future must be considered poor. ${ }^{72}$ The best that can be said for Chatha is that it raises the spectre of the latter and therefore renders the Belcher ruling somewhat unstable. ${ }^{73}$ This instability is perhaps confirmed by the subsequent decision of the Court of Appeal in McDonnell, in which a Court comprised of three judges, all of whom had been part of the Belcher Court, began by describing the Belcher ruling as obiter but then proceeded to criticise the appellant for failing to lodge separate

65 Chatha (CA), above n 30.

66 Ibid, para 32.

67 Belcher (NZSC), above n 30.

68 See Blanchard, above n 50, 193.

69 Belcher (NZSC), above n 30, para 6.

70 Ibid, paras 7-8.

71 The possible point of overlap is that if the Belcher Court took the view, on the basis of Taunoa, that a declaration of inconsistency must always be sought before the court of first instance, this may perhaps have heightened their concern about the risk of the criminal process being diverted into collateral issues.

72 For further comment on the Supreme Court's failure to grant leave in Belcher see Part III B 8 What is left and when, if ever, will it be exercised?

73 Though see $R v$ Chilton [2006] 2 NZLR 341 (CA) in which the Court of Appeal affirmed previous case law stipulating that it will need good reason to overrule its earlier decisions. 
civil proceedings in the light of it, noting that Belcher had "clearly stated that declarations of inconsistency could not be issued in criminal proceedings." 74

The correctness of the Belcher Court's finding as to the absence of a declaratory jurisdiction in criminal proceedings deserves careful and considered examination. In the context of this article, however, three passing observations must suffice. First, it is to be noted that the United Kingdom and Australian statutory regimes defy the Belcher Court's insistence that such declarations are, by nature, "civil" as in none of these jurisdictions is the relief so limited. ${ }^{75}$

Secondly (and drawing further on the comparative context), the position in these three jurisdictions differs with respect to whether the power to make such declarations has been vested in criminal trial courts or is only available on appeal in criminal cases. In the United Kingdom, the power to make declarations of incompatibility is not available to criminal trial courts ${ }^{76}$ - in part, it seems, to counteract the concern adverted to by the Belcher Court about the criminal trial process being diverted into collateral challenges. ${ }^{77}$ In the ACT and Victoria, on the other hand, the power is reposed in their respective supreme courts, the trial divisions of which do try certain serious criminal offences. ${ }^{78}$ The further concern expressed by the Belcher Court - that it would be anomalous for High Court judges to have jurisdiction to grant declarations of inconsistency in criminal trials if District Court judges do not have such jurisdiction ${ }^{79}$ - is perhaps partially met in the design of the Victorian regime through the inclusion of a referral power to enable any court or tribunal to refer questions of law relating to the application of the Charter to the Supreme Court. ${ }^{80}$ The ACT Human Rights Act does not, however, contain an equivalent referral power. ${ }^{81}$

74 McDonnell, above n 52, paras 123-131.

75 Human Rights Act 1998 (UK), s 4; Human Rights Act 2004 (ACT), s 32; Charter of Human Rights and Responsibilities Act 2006 (Victoria), s 36. See Belcher (CA 2), above n 30, para 13.

76 For a list of the United Kingdom courts empowered to make declarations of incompatibility, see Human Rights Act 1998 (UK), s 4(5). Though these include the High Court of England and Wales and Northern Ireland (s 4(5)(e)), this Court does not hear criminal trials. The Scottish High Court of Justiciary does hear criminal trials but only its appellate division has been given the power to make declarations of incompatibility: s 4(5)(d). The only way that a declaration of incompatibility could be sought prior to the conclusion of a criminal trial, therefore, is if an appeal was taken against a ruling of the trial judge during the course of the trial.

77 See Anthony Lester, David Pannick and Javan Herberg (eds) Human Rights Law and Practice (3 ed, LexisNexis, London, 2009) 50-51; Belcher (CA 2), above n 30, para 13.

78 Human Rights Act 2004 (ACT), s 32; Charter of Human Rights and Responsibilities Act 2006 (Vic), s 36.

79 Belcher (CA 2), above n 30, para 14

80 Charter of Human Rights and Responsibilities Act 2006 (Vic), s 33.

81 The Magistrates Court Act 1930 (ACT), s 219AB provides a limited power to refer questions of law in indictable matters but such referrals are only available on the application of either the Attorney-General or 
Thirdly, the Belcher Court is, with respect, right to remind us that in New Zealand, the jurisdictions of the District Court and the two appellate courts (the Court of Appeal and Supreme Court) are statutory and that, accordingly, if a jurisdiction to make declarations of inconsistency is to be found, precise attention must be given to the statutory pathways that will support it, both at first instance and on appeal. For example, given the constitutional significance of the declaration of inconsistency question, it would surely be anomalous to identify a first instance jurisdiction in the High Court (which does have inherent jurisdiction) if an appropriate avenue for appeal did not also exist.

These observations reinforce, more generally, the difficulties attendant upon creating such a declaratory jurisdiction by implication. Whether these difficulties are surmountable, however, deserves separate and detailed examination elsewhere.

\section{No District Court jurisdiction in civil proceedings?}

In developing its reasons for why there is no jurisdiction to make declarations of inconsistency in criminal cases, it will be noted that the Court of Appeal in Belcher asserted that there is no jurisdiction for District Court judges to grant declarations of inconsistency in civil proceedings. ${ }^{82}$ The Court did not, however, give reasons for this conclusion and, in the circumstances, it is best regarded as obiter. The District Court's civil jurisdiction is statutory and is laid out in Part 3 of the District Courts Act 1947. None of the heads of jurisdiction found there obviously comprehend a declaration power but whether it might be possible to read one in, bearing in mind section 6 of the NZ Bill of Rights (the interpretive direction) may require fuller interrogation in future cases. ${ }^{83}$

\section{Jurisdiction under the Declaratory Judgments Act 1908?}

In Boscawen v Attorney-General, the plaintiffs sought declarations that aspects of the Electoral Finance Act 2007 unjustifiably breached the rights to vote and to freedom of expression contained in the NZ Bill of Rights. ${ }^{84}$ They relied on the Declaratory Judgments Act 1908 (the DJA), which empowers the High Court to make declarations as to the meaning and effect of legislation, as the

the Director of Public Prosecutions, and only at the conclusion of the proceedings. Rights to appeal conviction and sentence are, of course, also available.

82 Belcher (CA 2), above n 30, para 14.

83 Attention would need to focus on s 29, which gives the District Court jurisdiction "to hear and determine any proceeding where the debt, demand, or damages, or the value of the chattels claimed, is not more than $\$ 200,000 \ldots$... Bearing in mind s 6 of the NZ Bill of Rights, might it be possible to characterise an application for a declaration as a "demand", and to rely on s 29 even though the amount of damages claimed is $\$ 0$ ? Or might this section provide a jurisdictional gateway where Baigent damages are claimed and declaratory relief is sought in the alternative?

84 NZ Bill of Rights, ss 12 and 14. 
basis for granting relief. ${ }^{85}$ In the High Court, Clifford J struck out the claim, relying on wellestablished case law under the DJA that the courts will not answer questions that are "abstract" in the sense that the pleadings do not disclose a "dispute" between the parties. ${ }^{86}$ It is not clear whether his Honour meant to suggest that any application for a declaration of inconsistency would inevitably be abstract because it would not be binding and thus would not affect the legal relationship between the parties. Alternatively, he may simply have meant that there was no "dispute" in Boscawen because the pleadings did not allege that the offending legislation had affected the plaintiffs themselves in their attempts to engage in political expression. Rather, the Boscawen claim was selfconfessedly abstract - the plaintiffs argued that the New Zealand courts should assert a power to give advisory opinions on the compatibility of legislation divorced from any particular fact situation.

Assuming that Boscawen reflects this latter and narrower concern, the question whether the DJA can ever provide jurisdiction for a declaration of legislative inconsistency remains unanswered. At first glance, though, the concept of a non-enforceable advisory declaration sits rather uneasily with the language of the DJA, which contemplates binding declarations on the meaning of legislation. ${ }^{87}$ Further, it is not clear what is to be gained from invoking this jurisdiction rather than relying directly on the NZ Bill of Rights and the inherent jurisdiction of the High Court. And if there is little to be gained, there may be something to be lost - as Boscawen itself illustrates. Case law under the DJA may create jurisdictional barriers that would not necessarily carry across to a novel jurisdiction developed in reliance on the NZ Bill of Rights itself. For that reason, future plaintiffs may be illadvised, from a tactical perspective, to invoke the DJA as the sole jurisdictional basis for the grant of such declaratory relief.

\section{No abstract claims}

If Clifford J's only reason for objecting to the Boscawen claim was that the DJA did not provide a suitable basis for relief, then striking out the claim was rather heavy handed. That, though, invites the question whether the objection that a claim is "abstract" will rule out a declaration of inconsistency even if the plaintiffs rely solely on the NZ Bill of Rights for the jurisdiction to grant such relief? That question was raised when Boscawen came before the Court of Appeal as the plaintiffs had conceded by that point that jurisdiction was not available under the DJA. ${ }^{88}$ Though the Court of Appeal did not make a clear ruling on the point, it did express doubt as to whether there

85 Boscawen v Attorney-General (2008) 8 HRNZ 520 (HC) [Boscawen (HC)]. Ibid, paras 52-53.

87 See especially Declaratory Judgments Act 1908, s 4.

88 Boscawen (CA), above n 23. For a fuller analysis of the Court of Appeal decision in Boscawen see Claudia Geiringer "Declarations of Inconsistency Dodged Again" [2009] NZLJ 232 ["Declarations of Inconsistency"]. 
is a jurisdiction to grant declarations of inconsistency in respect of abstract claims. O'Regan $\mathrm{J}$ for a unanimous Court noted that the New Zealand courts "are not well-placed to give opinions without a specific factual background to assess the inconsistencies". 89

The Boscawen Court's reservations about abstract claims are, with respect, likely to be shared by other New Zealand judges. ${ }^{90}$ The strongest argument for the existence of an implied declaratory jurisdiction under the NZ Bill of Rights is the one derived from Simpson $v$ Attorney-General [Baigent's Case] that, although the NZ Bill of Rights is silent as to remedies, the "ordinary range of remedies will be available". ${ }^{91}$ Declaratory relief in the context of a concrete factual dispute is arguably part of that ordinary range of remedies. An advisory jurisdiction to make general pronouncements on the compatibility of legislation with the NZ Bill of Rights, divorced from any particular fact situation, is not. Whether or not such an advisory jurisdiction is desirable as a matter of policy, it is one step further than the New Zealand courts are likely to want to travel on the basis of implication alone.

It is perhaps interesting to note that even in those jurisdictions that have conferred on the courts a power to make declarations of inconsistency, there appear to be considerable barriers to abstract claims. In the United Kingdom, the Court of Appeal has held that standing to seek a declaration of incompatibility is restricted by analogy with section 7 of the UK Human Rights Act, which confers standing to bring claims against public authorities on "victims" of rights violations. ${ }^{92}$ The two Australian jurisdictions have not yet tackled this question. However, both Australian charters prohibit freestanding applications for declarations of inconsistency - such declarations can only be sought in the context of proceedings that are already before their respective supreme courts. ${ }^{93}$ This may impact on the abstractness question as the ordinary rules of standing may well apply to such claims.

The apparent outlier in this respect is New Zealand's Human Rights Review Tribunal, exercising its express declaratory jurisdiction under the NZ Human Rights Act. It has refused to recognise any standing requirement, a position that has been upheld by the High Court on judicial review. ${ }^{94}$ This

89 Boscawen (CA), above n 23, para 54 and more generally, paras 50-55.

90 See Geiringer "Declarations of Inconsistency", above n 88.

91 Simpson v Attorney-General [Baigent's Case] [1994] 3 NZLR 667, 676 (CA) Cooke P [Baigent's Case].

92 Taylor v Lancashire County Council [2005] 1 WLR 2668, paras 37-44 (CA Civ) Lord Woolf CJ for the Court [Taylor]. See also Rusbridger, above n 63, para 35 Lord Hutton. Compare ibid, para 21 Lord Steyn. And see Richard Clayton and Hugh Tomlinson (eds) The Law of Human Rights (Oxford University Press, Oxford, 2009) vol 1, 2018-2021, criticising the approach taken in Taylor.

93 Human Rights Act 2004 (ACT), s 32; Charter of Human Rights and Responsibilities Act 2006 (Vic), s 36.

94 Child Poverty Action Group v Attorney-General (2005) 7 HRNZ 931 (HRRT); Child Poverty Action Group v Attorney-General (2006) 18 PRNZ 295 (HC). See also Howard v Attorney-General (No 1) HRRT15/06, 11 December 2006, paras 30-33. 
approach, though, is dependent on the particular statutory context in which the Tribunal operates and is unlikely to be brought across by analogy into the development of an implied jurisdiction under the NZ Bill of Rights. ${ }^{95}$

Accepting, then, that abstractness may be a legitimate objection to the exercise of an implied jurisdiction to make declarations of inconsistency under the NZ Bill of Rights, there is nevertheless a real danger of the abstractness point being pressed too far. The issue of abstractness will not always present in such a stark form as it did in Boscawen and will often give rise to questions of degree and kind. Further, there is force in the argument that those who wish to challenge rightsrestricting legislation should not have to wait for their rights to be breached before seeking a declaration. The jurisprudence of the European Court of Human Rights on the "victim" requirement in article 34 of the European Convention (on which section 7 of the UK Human Rights Act is based) reflects this concern. In a number of cases, the Court has found it to be sufficient that a complainant runs the risk of being directly affected by an offending measure, even if he or she has not yet been so affected. ${ }^{96}$ In the absence of a statutory standing requirement, the New Zealand courts ought, if anything, to be able to take a more liberal approach to the abstractness question. It may, therefore, be better to treat the question as one going to discretion rather than jurisdiction (as is, in fact, generally the case with respect to the abstractness requirement under the DJA).

\section{No freestanding application for a declaration}

A further and important question is whether the courts will acknowledge or exercise a jurisdiction to grant declarations of inconsistency when this is the only relief sought from the Court. A number of the recent Court of Appeal and Supreme Court cases have contained comments evincing an unwillingness to engage with requests for declarations of inconsistency if the subject matter of the proposed declaration is not closely related to a question of statutory interpretation or other more orthodox question that has come before them. ${ }^{97}$ For example, in refusing leave to appeal against a decision of the Court of Appeal dismissing an appeal against sentence in $R v$ Manawatu, the three Supreme Court judges who considered the application noted that the challenge did not

95 For a discussion of the standing question in the context of the legislative history of New Zealand antidiscrimination protections see Child Poverty Action Group v Attorney-General (2006) 18 PRNZ 295 (HC), above $\mathrm{n} 94$.

96 For example Campbell and Cosans v United Kingdom (1982) 4 EHRR 293 (ECtHR). By virtue of s 7(7) of the Human Rights Act 1998 (UK), the victimhood requirement in s 7 is to be developed consistently with article 34 of the European Convention of Human Rights. For a recent review of the relevant case law of the European Court see D J Harris and others Harris, O'Boyle \& Warbrick: Law of the European Convention on Human Rights (2 ed, Oxford University Press, Oxford, 2009) 790-796.

97 See Taunoa (NZSC Decision on Stay), above n 30, para 4; Manawatu (NZSC), above n 30, para 6; Belcher (NZSC), above n 30, para 6; Exley (CA), above n 30, para 20; Exley (NZSC), above n 40, para 2; Chatha (CA), above n 30, para 32; Wenzel, above n 30, para 4. 
seem to relate to the appropriateness of the sentences in fact imposed on Mr Manawatu and then observed as follows: 98

The application rather seeks to bring a systemic challenge to aspects of the system for determining criminal appeals in the Court of Appeal. The challenge is concerned with the policy of the legislation, in particular in relation to the Criminal Appeal Division and present restrictions on delivery of separate judgments in the Court. It is not suggested that it is open to the Court to interpret the legislation in a way that would be more consistent with rights protected by the Bill of Rights and the Covenant. Nor is it suggested that the Court of Appeal is acting outside of what the legislation mandates.

If the Supreme Court meant, in the italicised passage, to signal that a declaration of inconsistency can only be sought if ancillary to a claim that the legislation has been incorrectly interpreted or applied, then this amounts to another significant limit on the putative jurisdiction. That is particularly so if the Belcher rule limiting the availability of declarations of inconsistency to civil proceedings stands. Take, for example, someone in the position of Mr Belcher who brings and loses a criminal appeal relating to the interpretation and application of the relevant legislation. If there is no jurisdiction to consider a freestanding application for a declaration of inconsistency, then Mr Belcher would be denied the opportunity to bring a subsequent civil action for a declaration of inconsistency in relation to the same subject matter. That is because all issues of interpretation and application of the legislation will have been resolved in the criminal appeal. More generally, this limit on the jurisdiction, if it exists, would create an unfortunate incentive for a plaintiff to dress an application for a declaration in the sheep's clothing of an untenable interpretation argument.

This latter concern has not, however, prevented the two Australian jurisdictions from limiting declaratory relief in exactly that way. As noted above, in both the ACT and Victoria, a declaration of inconsistency can only be sought in the context of proceedings that are already before the relevant Supreme Court. Thus, freestanding applications for declaratory relief are precluded. ${ }^{99}$

7 Not available if Parliament is seised of the question?

This proposition derives from the decision of the Court of Appeal in Manawatu. ${ }^{100}$ The subject matter of the proposed declaration in Manawatu was section 398(1) of the Crimes Act 1961, which restricted the delivery of separate judgments (and thus dissenting judgments) in criminal appeals in the Court of Appeal. At the Court of Appeal hearing, the appellant's counsel criticised the judges of

98 Manawatu (NZSC), above n 30, para 6 (emphasis added).

99 Human Rights Act 2004 (ACT), s 32; Charter of Human Rights and Responsibilities Act 2006 (Victoria), s 36. The significance of this restriction is, however, less than it would be in the New Zealand context because, as discussed above, declarations of inconsistency in those jurisdictions are not confined to civil proceedings.

100 Manawatu (CA), above n 30. 
the Court of Appeal for their alleged "failure to speak out against s 398(1)". ${ }^{101}$ O'Regan $\mathrm{J}$ for a unanimous bench of five roundly rejected this criticism, noting that section 398(1) was, in fact, in the process of being repealed and that this process had been instigated by the very body of judges that counsel presumed to criticise. ${ }^{102}$ The Court declined to examine whether section 398(1) violated provisions in the NZ Bill of Rights, considering that it would be "gratuitous and unnecessary" to do so in the circumstances just described. ${ }^{103}$

This suggests yet another potential limit on the exercise of the implied declaratory jurisdiction, though one presumably going to the discretion to grant relief rather than to jurisdiction. The rationale is, presumably, that "dialogue" is unnecessary and perhaps unwelcome if the legislative branch is getting along well enough on its own. It is interesting to note, however, that the Court of Appeal in Boscawen did not choose to utilise this particular technique of avoidance even though, by the time it issued its decision, a Bill repealing the Electoral Finance Act 2007 was before the House and being enacted under urgency. ${ }^{104}$ It is also worth noting that this approach has not yet found favour with the Human Rights Review Tribunal (exercising its express declaratory jurisdiction under the NZ Human Rights Act). ${ }^{105}$ Nor is it an approach that has yet been taken by the United Kingdom courts, ${ }^{106}$ though in Ghaidan v Godin-Mendoza Lord Millett observed that it "may be a matter for debate" whether a court should exercise its discretion to make a declaration if Parliament is already engaged in enacting remedial legislation. ${ }^{107}$

8 What is left and when, if ever, will it be exercised?

In sum, then, the recent case law has placed significant hedges around the circumstances, if any, in which an implied jurisdiction to make declarations of inconsistency can or should be exercised. Perhaps the two most significant are that it is not available in the course of criminal proceedings and, it seems, cannot be brought as a freestanding claim. Notably, all of the recent cases avoid answering the question whether, even if all of the conditions identified above have been met, a

101 Ibid, para 11.

102 Ibid, para 12. Section 398(1) was indeed subsequently repealed by the Crimes Amendment Act (No 2) 2008.

103 Manawatu (CA), above n 30, para 13.

104 In fact, the Electoral Amendment Act 2009 passed through all three of its readings on the very same day that the Court of Appeal handed down its decision.

105 See Howard v Attorney-General (No 2) HRRT15/06, 7 December 2007; Howard v Attorney-General (No 3) (2008) 8 HRNZ 378, paras 88-90.

106 See Bellinger v Bellinger [2003] 2 AC 467, paras 54-55 (HL) Lord Nicholls; ibid, para 79 Lord Hobhouse; $R(M) v$ Secretary of State for Health [2003] EWHC 1094 (QBD); Smith $v$ Scott [2007] CSIH 9 (Registration Appeal Court, Scotland). In none of these cases, though, was the possibility of a legislative response as far advanced as in Manawatu.

107 Ghaidan v Godin-Mendoza [2004] 2 AC 557, para 56 (HL) Lord Millett [Ghaidan]. 
residual jurisdiction to make such declarations exists at all. In some instances, the courts' reluctance to enter that debate can readily be understood in the light of factors such as the late stage at which the request for a declaration or inconsistency was made ${ }^{108}$ or the disconnection between the thrust of the appeal and the subject matter of the proposed declaration. ${ }^{109}$ Read as a whole, however, the case law evinces a marked reluctance on the part of New Zealand judges to engage with the existence of a declaration of inconsistency jurisdiction.

The Supreme Court's decisions in Hansen and Belcher, and the Court of Appeal's decision in Boscawen are particularly telling instances of this phenomenon. In Hansen, a majority of the Supreme Court exercised the substantive jurisdiction discussed above ${ }^{110}$ to examine the compatibility of a reverse onus provision found in the Misuse of Drugs Act 1975 and concluded that on its ordinary meaning, the legislation breached the NZ Bill of Rights in a manner that could not be justified in a free and democratic society in terms of section 5 . It then examined the possibility that there might be an alternative rights-consistent interpretation and rejected it, concluding that the "ordinary" rights-violating interpretation was the only legitimate meaning that could be given to the legislation. ${ }^{111}$ At that point one might have expected their Honours at least to consider whether to grant a declaration of inconsistency - the appellant's counsel had certainly requested them to do so in written submissions. Nevertheless, none of the Supreme Court justices even adverted to the possibility that a declaration could be made, let alone gave reasons for not making one.

Shortly thereafter, the Supreme Court refused to grant leave to appeal in Belcher against the finding that there is no jurisdiction to make declarations of inconsistency in criminal cases. ${ }^{112}$ This was despite the fact that Belcher clearly raised weighty human rights issues concerning the retrospective application of a regime of ongoing "supervision" (somewhat like parole conditions) that can be tacked onto the end of a person's sentence for certain types of sex offending. As mentioned above, that regime had attracted an adverse report under section 7 of the NZ Bill of Rights from the (Labour) Attorney-General when it was introduced to the House, and amendments to it have since attracted a further report from the new (National) Attorney-General. ${ }^{113}$ The

108 See Chatha (CA), above n 30; Wenzel, above n 30.

109 See Taunoa (NZSC Decision on Stay), above n 30; Manawatu (NZSC), above n 30; Chatha (CA), above n 30.

110 See Part III A Substantive Jurisdiction Definitively Established.

111 Hansen, above n 1, para 149 Tipping J; ibid, paras 234 and 257 McGrath J; ibid, paras 281 and 290 Anderson J. See also ibid, paras 5 and 41 Elias CJ. Compare ibid, para 83 Blanchard J.

112 Belcher (NZSC), above n 30.

113 "Report of the Attorney-General under the New Zealand Bill of Rights Act 1990 on the Parole (Extended Supervision) and Sentencing Amendment Bill" E63 www.parliament.nz (accessed 12 June 2009); "Report of the Attorney-General under the New Zealand Bill of Rights Act 1990 on the Parole (Extended Supervision Orders) Amendment Bill" J4 www.parliament.nz (accessed 15 July 2009). 
Supreme Court has subsequently refused leave to appeal in three further cases in which the question whether there is a jurisdiction to make declarations of inconsistency in criminal cases has been at issue. 114

In Boscawen, the plaintiffs had pursued two distinct lines of attack. First, they sought to review the Attorney-General's failure to issue an adverse report under section 7 of the NZ Bill of Rights on the Electoral Finance Bill when it was introduced to the House and, secondly, they sought nonbinding declarations of inconsistency in respect of the legislation as eventually enacted. With respect to the first line of attack, the Court of Appeal held that the principle of comity precluded review of the Attorney-General's reporting function under section 7 of the NZ Bill of Rights. ${ }^{115}$ The Court then held (without any real explanation) that its conclusion with respect to the nonjusticiability of section 7 made it "unnecessary to deal with the issues relating to declarations of inconsistency". 116 With respect, this conclusion is mystifying. The non-justiciability of section 7 was irrelevant to the question whether a declaration of inconsistency was available with respect to the enacted legislation. The readiness with which the Court concluded otherwise can only be made sense of as another example of the marked reluctance of New Zealand judges to engage with the existence of an implied declaratory jurisdiction. ${ }^{117}$

The recent case law does not, however, go so far as to rule out the possibility that a jurisdiction to make declarations of legislative inconsistency (at least in civil proceedings) can be implied from the terms of the NZ Bill of Rights and it is perhaps significant that no judge has yet wished to close that door. ${ }^{118}$ My cautious prediction is that at some point in the future, the New Zealand courts will recognise a carefully circumscribed jurisdiction to make declarations of inconsistency. In the face of the express declaration of inconsistency powers now included in a growing number of statutory human rights charters around the world, not to mention in the NZ Human Rights Act, constitutional objections to the exercise of such a jurisdiction - for example, the argument that it would constitute an unacceptable judicial intrusion on the domain of Parliament - lose much of their potency. ${ }^{119}$

114 Exley (NZSC), above n 40; Chatha $v$ R [2009] NZSC 21; Wenzel, above n 30.

115 Boscawen (CA), above n 23, paras 27-42.

116 Ibid, paras 48 and 55.

117 For more on this aspect of the Boscawen decision see Geiringer "Declarations of Inconsistency", above n 88.

118 Though see Miller v New Zealand Parole Board (2008) 24 CRNZ 104 (HC), especially paras 35 and 45, a case in which declarations of inconsistency appear to have been sought and in which the Judge stressed repeatedly that the relevant legislation could not be reviewed by reference to "external standards".

119 For an account of the main arguments against recognising the availability of implied declaratory relief (as well as responses to those arguments) see Butler, above n 27, especially 52-55. In Australia, separation of powers issues continue to cast a shadow over the possibility of a similar model being adopted at the federal level, but that is a feature of the precise wording of the federal constitution and has not been thought to create a problem in the Australian states and territories - at least so long as state/territory courts are 
There is nothing in the language of section 4 of the NZ Bill of Rights to expressly preclude such a remedy, and its evolution would seem to be consistent with the liberal approach foreshadowed in Baigent's Case to the development of effective remedies. ${ }^{120}$

Even if such a jurisdiction is eventually confirmed, however, the case law discussed above suggests that the prospects of it actually being utilised on a regular basis are poor. The Supreme Court's decisions in Hansen and Belcher are, again, significant in this regard. In Hansen, the judge that came closest to addressing explicitly the declaration of inconsistency question was McGrath J. In a passage already quoted above, he maintained that the New Zealand courts should not shirk their responsibility to indicate in their decisions that legislation is inconsistent with the NZ Bill of Rights and cannot be saved through interpretation. ${ }^{121}$ He then added: "Normally that will be sufficiently apparent from the court's statement of its reasoning". ${ }^{122}$ I read that sentence as suggesting that a formal declaration will not normally be required.

In Belcher, McGrath, Tipping and Blanchard JJ refused leave to appeal to the Supreme Court because they considered that, regardless of whether there was any jurisdiction to grant a declaration of inconsistency, it was "entirely appropriate" for the Court of Appeal "to leave the matter in essentially the same way as it was subsequently left by the majority of this Court in $R v$ Hansen", that is, by describing the inconsistency but making no formal declaration. The judges also noted that it was "of some moment ... that no issue concerning s 5 was required to be determined in the necessary course of interpreting the legislation and resolving questions between the parties". ${ }^{123} \mathrm{~A}$ response in the form of a declaration was, the judges concluded, "quite unnecessary". 124

The correctness of these remarks can perhaps be questioned. Section 5 was arguably just as relevant to the interpretation issue in Belcher as it was to Hansen. Further, on one view, Belcher had not been left on the same footing as Hansen at all. In Hansen, the majority judges had clearly indicated their view that the relevant legislation limited the right to be presumed innocent in a manner that could not be justified in a free and democratic society by reference to section 5 . In contrast, in Belcher, there was no clear "indication" of inconsistency of the kind foreshadowed by McGrath $\mathrm{J}$ in the passage from Hansen quoted above. ${ }^{125}$ At a first Court of Appeal hearing, the

exercising state/territory rather than federal jurisdiction: see for example James Stellios "State/Territory Human Rights Legislation in a Federal Judicial System" (2008) 19 PLR 52.

120 Baigent's Case, above n 91.

121 Part III A Substantive Jurisdiction Definitively Established.

122 Hansen, above n 1, para 253.

123 Belcher (NZSC), above n 30, para 6.

124 Ibid.

125 Part III A Substantive Jurisdiction Definitively Established. 
Court had held that, on its ordinary meaning, the "extended supervision order" regime in the Parole Act 2002 constituted a prima facie breach of the prohibitions in the NZ Bill of Rights against retrospective penalties and double punishment. ${ }^{126}$ The Court had then decided to assume, for the purposes of the ensuing statutory interpretation argument, that this prima facie breach could not be justified in terms of section 5 . The Court had nevertheless concluded that no alternative rightsconsistent interpretation of the offending provisions was available and that, therefore, the offending legislation must stand. ${ }^{127}$ This raised the question whether a declaration of inconsistency should be made. At this point, however, the Court of Appeal had abandoned its assumption that the prima facie breaches of the NZ Bill of Rights were unjustified in terms of section 5, noting that it had not received sufficiently full argument on the point. The Court had therefore reserved that question, as well as the question whether there was jurisdiction to make declarations of inconsistency, for further argument at a later hearing. ${ }^{128}$ In the event, the Court of Appeal had only considered the question of jurisdiction at that subsequent hearing and had concluded, as discussed above, that it did not have jurisdiction. ${ }^{129}$

In the result, therefore, there was no clear indication from the Court of Appeal in Belcher as to whether or not the impugned legislation unjustifiably breached the NZ Bill of Rights and the Supreme Court was arguably wrong to conclude that a formal declaration was, for that reason at least, unnecessary. The broader point, though, is that like Hansen, Belcher indicates the view taken by the current Supreme Court that even if a jurisdiction does exist, the discretion to grant formal declaratory relief should only be exercised sparingly. It will normally be sufficient simply to "indicate" the inconsistency in the course of the reasoning. ${ }^{130}$ As Michael Taggart has said, that appears to be the "default setting". ${ }^{131}$ Neither Hansen nor Belcher offer any assistance in explicating the circumstances in which a court should depart from that default position and take the additional step of making a declaration, and it is not immediately clear what those circumstances might be if neither Hansen nor Belcher qualified. ${ }^{132}$ In contrast, the general tenor of jurisprudence from those jurisdictions with express declaration of inconsistency powers is that once an

\footnotetext{
126 Belcher (CA 1), above n 30, para 49.

127 Ibid, paras 50-56.

128 Ibid, paras 57-59.

129 Belcher (CA 2), above n 30, see para 4.

130 See also McDonnell, above n 52, para 123(b).

131 Taggart, above n 18, 344.

132 Ibid, 344-345.
} 
inconsistency has been established, the courts will be slow to refuse relief, notwithstanding the discretionary nature of such relief. ${ }^{133}$

None of this rules out the possibility that once such a jurisdiction has been established, certain judges might, in certain circumstances, be prepared to exercise it. ${ }^{134}$ The exercise of such a jurisdiction is, however, counterintuitive for most New Zealand judges, who are not comfortable with being put in the role of critic of the legislative branch, and may also be wary of the political reaction this may provoke. The bulk of New Zealand judges are unlikely to make such declarations unless they have a clear direction from the senior judiciary that it is their duty to do so in cases involving unjustified breaches of the NZ Bill of Rights. The recent offerings from the appellate courts fall far short of such a direction.

In short, then, unless there is a marked change in the direction of recent case law, the prospects for an implied declaration of inconsistency power being exercised in any but the rarest of circumstances are poor.

\section{WHAT DIFFERENCE WOULD IT MAKE?}

To reiterate, then, the Supreme Court in Hansen has reaffirmed the jurisdiction of the New Zealand courts to examine the conformity of legislation with the standards contained in the NZ Bill of Rights and has suggested that this inquiry is an integral step in the process of interpreting and applying legislation. The New Zealand courts have not, however, embraced a formal remedial jurisdiction to issue declarations of inconsistency.

If the former is so, does the latter matter? In other words, if the Hansen methodology requires the courts to engage with legislative consistency with the NZ Bill of Rights, what difference does it make whether or not the courts go the further step of issuing a formal declaration?

Let us first assume that, in the post-Hansen world, judicial inquiries into the conformity of legislation with the NZ Bill of Rights will, indeed, become a routine part of judicial methodology. In order to decide whether formal declaratory relief would nevertheless serve a useful purpose, a key question that would presumably need to be addressed is whether a formal declaration is more likely to prompt a dialogue between the courts and the political branches of government - in other words, to prompt a political response of some kind to the problem that has been identified? Depending on

133 See in particular the cases from the (New Zealand) Human Rights Review Tribunal and the United Kingdom discussed at above nn 105 and 106. See also Lester, Pannick and Herberg, above n 77, 49-50; Clayton and Tomlinson, above n 92, 211.

134 Thomas J's dissenting judgment in Poumako, above n 24, is an example where a judge would have done so. 
the theory of dialogue to which you subscribe, ${ }^{135}$ this response might not necessarily need to amount to political submission to the will of the judiciary. For there to be dialogue, however, there would need to be evidence of some degree of political engagement with the concerns raised by the courts.

As of yet, there is little in the way of empirical data that could be drawn on in answering this question. The United Kingdom experience does not translate well in this regard because of the salutary effects on Westminster of the binding jurisdiction of the European Court of Human Rights. The United Kingdom government has every incentive to respond to a judicial declaration of incompatibility because failure to do so is likely to result in a successful application to the Strasbourg court. The United Kingdom regime is also unique in terms of the provision that it makes for such inconsistencies to be addressed by remedial order. ${ }^{136}$

No declarations have yet been made in either the ACT or Victoria although, interestingly, a Victorian County Court judge (who does not have the power to make a declaration) has indicated his view that Victorian legislation equivalent to the legislation at issue in Belcher is inconsistent with human rights. ${ }^{137}$ The question whether a formal declaration should be made in respect of that legislation is currently before the Victorian Supreme Court. From a "dialogue" perspective, it is perhaps also interesting to note that new legislation is currently before the Victorian Parliament that would substitute a new scheme that arguably addresses at least some of the human rights concerns identified by the Victorian courts.

To date, one declaration of inconsistency has been made by New Zealand's Human Rights Review Tribunal, in Howard $v$ Attorney-General (No 3) (Howard). ${ }^{138}$ At the time of writing, an appeal is still on foot from that decision so no formal response from the Government to the declaration is yet required. ${ }^{139}$ In fact, legislation that redresses the breach identified in Howard was enacted shortly after the Tribunal handed down its decision. ${ }^{140}$ That legislation had, however, been

135 For an interesting discussion of some of the different conceptions of "dialogue" that might play into the debate see Hickman, above n 4.

136 Human Rights Act 1998 (UK), s 10 and Schedule 2.

137 Secretary to the Department of Justice $v A B$ [2009] VCC 1132. A case is also currently proceeding through the Victorian courts concerning the presumption of supply (the issue in Hansen) so, from a "dialogue" perspective, it will also be interesting to follow the treatment of that case by both the courts and, if declarations are made, the political branches.

138 Howard v Attorney-General (No 3), above n 105.

139 See Human Rights Act 1993, s 92K, which requires the Minister responsible for the administration of the impugned enactment to present two reports to the House of Representatives within 120 days of the matter being finally determined: one bringing the declaration to the attention of the House and one advising on the Government's response to the declaration.

140 Injury Prevention, Rehabilitation, and Compensation Amendment Act (No 2) 2008. 
introduced to the House some six months before the Tribunal issued its decision so it is not possible to attribute its enactment directly to the fact that a declaration of inconsistency had been made. It is, of course, possible that the fact that an application for declaratory relief was on foot prompted the Government to expedite a legislative response.

In time, perhaps, the experiences in the ACT and Victoria, as well as under the NZ Human Rights Act, may provide an empirical basis for assessing the value of formal declaratory relief, but any comparisons will need to be drawn with great care. Quite apart from the obvious difficulties in comparing different political cultures, there are also dangers in assuming that the political response to a declaration made in the exercise of an express legislative power to do so would be similar to the political response to a declaration made under the NZ Bill of Rights in the absence of any express legislative regime. That is particularly so given that the express regimes all formalise the dialogue that such declarations are supposed to generate, most commonly, by requiring the Government to table a formal response to the declaration in the House. ${ }^{141}$

More tangibly, one apparent effect of granting declaratory relief is that it reverses the result in the case. If declaratory relief is sought and gained, then the case has presumably been won rather than lost. The very fact that this is so may make a challenge to offending legislation a more attractive option for an aggrieved person. There may also be costs implications as well as implications for the availability of legal aid. ${ }^{142}$ In practical terms, therefore, the granting of formal relief may significantly increase the likelihood that aggrieved persons will challenge the justifiability of legislative breaches of the NZ Bill of Rights.

For similar reasons, formal declaratory relief would almost certainly make it more likely that the media would report a case as a victory against the Government, thus increasing the political pressure on the Government to respond to the breach. It is interesting to note, for example, that the judicial "indication" of legislative inconsistency in Hansen received little or no media attention, whereas the formal declaration in Howard did receive some, albeit limited, media coverage. ${ }^{143}$

141 Human Rights Act 1993, s 92K; Human Rights Act 2004 (ACT), s 33; Charter of Human Rights and Responsibilities Act 2006 (Victoria), s 37.

142 See Butler, above n 27, 57-58. For examples from the United Kingdom of cases in which claimants were awarded costs after being granted a declaration of incompatibility see $R(H) v$ London North and East Region Mental Health Review Tribunal (Secretary of State for Health intervening) [2002] QB 1 (CA); and $R$ (Anderson) $v$ Secretary of State for the Home Department [2003] 1 AC 837 (HL). See also Lester, Pannick and Herberg, above n 77, 53, suggesting that an applicant who secures a declaration of incompatibility ought to be awarded costs. But contrast the discussion in Clayton and Tomlinson, above n 92, 222.

143 See for example Yvonne Tahana "Injured man beats ACC in ageism fight" (20 May 2008) The New Zealand Herald Auckland A3; Radio New Zealand Newswire (19 May 2008). In contrast, an electronic search of Newztext Newspapers disclosed no coverage of the Hansen decision. 
The above discussion, however, is premised on the assumption that in the post-Hansen world, judicial "indications" of inconsistency will be made in the same range of circumstances as might attract a declaration of inconsistency were there an express jurisdiction to make one. The more important point is that this assumption is patently incorrect. In many cases of legislative inconsistency with the NZ Bill of Rights, it is unlikely that any Hansen-inspired judicial "indication" of inconsistency will be forthcoming.

The Hansen methodology is primarily designed to resolve cases where an issue arises as to the correct interpretation or application of a statutory provision. Within the context of that methodology, the immediate purpose of a judicial "indication" of legislative inconsistency with the NZ Bill of Rights is to set up the need to consider whether a section 6-mandated (and therefore rightsconsistent) interpretation of the statute is available. This means that the situations in which the Hansen methodology most clearly demands examination of the consistency of legislation with the NZ Bill of Rights are those in which any inconsistency, if established, can be resolved through the device of interpretation. In contrast, the mechanism of the declaration of inconsistency is designed to advance the opposite situation - where a violation is established but cannot be remedied through the device of interpretation.

McGrath J's observations in Hansen as to the value in making such indications of legislative inconsistency (quoted above) ${ }^{144}$ could be read as suggesting that there is value in a court undertaking that examination in all cases, even if there is no realistic possibility of an interpretive solution to the alleged violation. That reading of his remarks is, however, counteracted by Exley. ${ }^{145}$ In Exley, the appellant's counsel had sought to get around the Belcher ruling as to the lack of jurisdiction in criminal cases by asking for what they termed a "Hansen declaration" - that is, by asking the Court to make its views on the inconsistency clear in the course of its reasoning. ${ }^{146}$ The Court of Appeal refused to do so. Chambers J, giving the reasons of the Court, noted as follows: ${ }^{147}$

Hansen was quite different. In Hansen, there was a legitimate question of statutory interpretation as to the correct meaning of s 6(6). The Supreme Court was justified in investigating the consistency of s 6(6) with the Bill of Rights, because s 6 of the Bill of Rights required the court to give an enactment a meaning consistent with the rights and freedoms contained in the Bill of Rights if possible. But there is no similar dispute here. The wording of s 87 of the Sentencing Act is clear. Hansen is not authority for the proposition that the courts are empowered to conduct what are effectively commissions of inquiry into acts of the legislature and executive to see whether they measure up to the requirements of the Bill of Rights and the Covenant.

144 Part III A Substantive Jurisdiction Definitively Established.

145 Exley (CA), above n 30; Exley (NZSC), above n 40.

146 Exley (CA), above n 30, para 19.

147 Ibid, para 20. 
McGrath J was one of three Supreme Court justices who refused Mr Exley leave to appeal. ${ }^{148}$ In its leave decision, the Court agreed with the Court of Appeal that: "There is no bona fide interpretation issue so a 'Hansen' analysis is not required". 149

If Exley is correct, then the obligation on courts under the Hansen methodology to examine whether legislation is human rights compliant only truly arises when the aggrieved person is able to construct a bona fide interpretation issue over the meaning of the relevant legislation. Further, if, on examining that "bona fide" interpretation issue, the Court concludes that a human rights-consistent interpretation of the statute is, indeed, available then the NZ Bill of Rights issue is resolved and there is no need for any judicial indication to the political branches that the legislation breaches human rights standards. The Hansen "indication" of inconsistency is therefore only available if there is an interpretation argument that is regarded as sufficiently "bona fide" to justify embarking on the Hansen methodology but which ultimately fails. ${ }^{150}$

It is thus only a fairly narrow category of cases that is, on this reading, truly amenable to a Hansen indication of inconsistency. What is more, even if a case falls within this narrow category, we should not assume that courts will always faithfully apply that methodology. For example, Belcher highlights a technique that is available to the courts to avoid having to do so. It will be remembered that, in the first Court of Appeal decision in Belcher, the Court "assumed" for the purposes of completing the interpretation exercise that the legislation unjustifiably breached the NZ Bill of Rights. Having concluded that no rights-consistent interpretation was nevertheless available, the Court then discarded this assumption. In this way, the Court avoided giving a clear indication, for the purposes of any dialogue with the political branches, of its opinion as to whether or not the legislation created an unjustified breach of the NZ Bill of Rights. ${ }^{151}$ By refusing leave to appeal in Belcher on the grounds that the Court of Appeal's approach was "entirely appropriate", the Supreme Court has, wittingly or not, legitimated this avoidance technique.

In short, then, it is unsafe to conclude that judges will use the Hansen methodology to enter into a routine dialogue with the political branches as to the NZ Bill of Rights-consistency of legislation. A review of the case law during the first two-and-a-half years since Hansen was handed down confirms this. Certainly, there are examples post-Hansen of judges utilising the Hansen methodology to examine the consistency of legislation with the NZ Bill of Rights. The cases in

148 Exley (NZSC), above n 40.

149 Ibid, para 2. See also the comments of the Supreme Court in Wenzel, above n 30, para 4; and of O’Regan J in McDonnell, above $\mathrm{n}$ 52, para 123(c).

150 Hansen itself fell into this category. In that case, the bona fides of the interpretation argument arose from the fact that a House of Lords decision supported the interpretation advanced by the appellant: $R v$ Lambert [2002] 2 AC 545 (HL). Nevertheless, ultimately the Supreme Court held that in the New Zealand context, such an interpretation was not available.

151 Belcher (CA 1), above n 30, paras 57-59. 
which judges have been prepared to do so, though, are those in which the Court ultimately intends to conclude either that any legislative inconsistency can be resolved through interpretation ${ }^{152}$ or (and more commonly) that any legislative intrusion on rights is justifiable in terms of section $5 .{ }^{153} \mathrm{My}$ research has not uncovered a single post-Hansen example of the Courts examining legislation and concluding that it violates human rights standards.

There are, though, a number of cases in which judges have refused to assess legislation against human rights standards because they do not consider that there is a bona fide interpretation issue in the case. ${ }^{154}$ There are also examples of judges utilising the Belcher technique of "assuming" inconsistency for the sole purpose of examining (and then dismissing) an interpretation argument. ${ }^{155}$ At least some of these cases raised weighty human rights issues of a kind that would doubtless have been of interest to a constitutional court with accepted powers to review legislation against human rights standards. For example, Kirk $v$ Electoral Commission raised a question of the correct interpretation of a provision in the Electoral Finance Act 2007 relating to third party election spending. If MacKenzie J, the judge in the case, had been faithful to the Hansen methodology, he would have proceeded to consider whether of not that provision unjustifiably limited the rights to vote and to freedom of expression. Whether or not he ought ultimately to have concluded that the legislation unjustifiably breached the NZ Bill of Rights is beyond the scope of this article. Suffice to note that the human rights issues implicated by this legislation were attracting considerable interest within the community, in part because of a perception that they had not been dealt with well by the Government of the day during the legislative process. Under a truly "dialogical" bill of rights, one might have thought that this was exactly the kind of issue that a court might have wished to express a view on. Yet MacKenzie J avoided the question of legislative consistency with the NZ Bill of

152 For example Gordon-Smith v R [2009] NZSC 20, paras 72-88 McGrath J dissenting.

153 For example Television New Zealand Ltd v Solicitor-General [2009] NZFLR 390, paras 60-76 (CA) Robertson J for O'Regan and Robertson JJ; $R v$ Wenzel [2009] NZCA 130, paras 33-36 (CA) Robertson J for the Court (though note his view that, as there was a clear and unambiguous legislative direction, a Hansen assessment was "a rather non-productive exercise").

154 For example Plakas v Police (19 June 2008) HC AK CIV2008-404-2412; Exley (CA), above n 30, para 20. See also Wikio v Attorney-General (2008) 8 HRNZ 544 (HC) and Miller v New Zealand Parole Board, above n 118 - two decisions of MacKenzie J concerning the independence and impartiality of certain judicial and quasi-judicial bodies (as guaranteed by ss 25(a) and 27 of the NZ Bill of Rights). In the first, MacKenzie J veered back and forth throughout the judgment between a willingness to "venture outside the strict limits of the judicial role" in order to examine the constitutionality of the legislation in terms of the standards contained in the NZ Bill of Rights and a retreat into the argument that challenges to the constitutionality of legislation are non-justiciable (compare paras 45 and 73-75 with paras 111-112, 145 and 148). By the second, his Honour was no longer prepared to entertain such questions, stressing several times through the judgment that in New Zealand, legislation cannot be reviewed by reference to standards "external to the Act": paras 34, 35 and 45.

155 Kirk v Electoral Commission [2008] 3 NZLR 125, para 28 (HC); Aziz v Chief Executive of the Ministry of Social Development (17 March 2009) HC WN CIV2007-485-1271, paras 30-31. 
Rights by deploying the Belcher technique of assuming inconsistency solely for the purpose of tackling (and rejecting) the interpretation argument. ${ }^{156}$

\section{CONCLUSION}

The early evidence as to the application of Hansen, therefore, suggests that the courts have not embraced with enthusiasm the licence given in Hansen to examine legislation against human rights standards and to indicate any resulting inconsistency. We should not find this surprising. The question of legislative compatibility with the NZ Bill of Rights - particularly in cases that hinge on the justifiability criteria in section 5 - occupies a territory on the border of law and policy that courts are generally reluctant to enter. The jurisprudential hoops involved in conducting a section 5 inquiry, as articulated by the Moonen and Hansen Courts, are (sometimes needlessly) complex and can require the resolution of difficult and unfamiliar kinds of evidential questions. ${ }^{157}$ More generally, and as already suggested above, many New Zealand judges are simply not comfortable with being placed in the role of critic of the legislative branch.

For these reasons and no doubt others, it is hard to shift the judicial mindset towards a selfconscious and routine dialogue with the legislative branch of the kind that declarations of inconsistency are thought to facilitate. The easiest way to effect this shift in mindset is to provide clear legislative authority for the courts to grant formal declaratory relief. The experience in the United Kingdom and the limited experience to date under the NZ Human Rights Act suggest that once such express legislative authorisation is given, adjudicative bodies are quick to rise to the challenge and slow to exercise their undoubted discretion to refuse relief. ${ }^{158}$

This is not to suggest that no inter-branch dialogue can or does occur in New Zealand in the absence of such a formal jurisdiction. ${ }^{159}$ The interpretive direction in section 6 of the NZ Bill of Rights itself facilitates a softer form of dialogue with the political branches. Further, occasional instances of harder-edged dialogue in the form of judicial calls for legislative reform will no doubt

156 Kirk, above n 155, para 28.

157 On the complexity of s 5 jurisprudence see Claudia Geiringer and Steven Price "Moving from SelfJustification to Demonstrable Justification - the Bill of Rights and the Broadcasting Standards Authority" in Jeremy Finn and Stephen Todd (eds) Law, Liberty, Legislation: Essays in Honour of John Burrows QC (LexisNexis, Wellington, 2008) 295, 313-315. On the use of legislative fact evidence see Ben Keith "Seeing the World Whole: Understanding the Citation of External Sources in Judicial Reasoning" in Geiringer and Knight (eds), above n 1, 163, 170-174.

158 The United Kingdom experience also suggests that the availability of formal declaratory relief may have a galvanising effect on the willingness of courts to find an interpretive solution to a problem of legislative incompatibility, but further exploration of that issue is beyond the scope of this paper. See Ghaidan, above $\mathrm{n}$ 107.

159 My colleague, Dr Petra Butler, has a project under way in which she is tracking more fully the inter-branch dialogue that occurs under our bill of rights. 
continue to take place both inside and outside the space provided by the NZ Bill of Rights, just as it has always done. ${ }^{160}$ It is likely, even, that the Hansen methodology may effect a modest increase in the instances of such inter-branch exchanges.

The point, though, is that in the absence of a clear statement from the senior judiciary that there is an implied jurisdiction to make declarations of inconsistency and that it is the duty of the courts to use it in appropriate cases, the courts' participation in any such "dialogue" is likely to continue for some time to be far more sporadic and sotto voce than in those jurisdictions with express declaration of inconsistency powers.

In short, we cannot rely on the implied declaration of inconsistency jurisdiction to found a robust dialogue, of the kind that is emerging in the United Kingdom, between the judicial and political branches of government. Whether we need a more robust dialogue of this kind falls outside the scope of this article. If that is the sort of dialogue that we wish our bill of rights to facilitate, however, we would do best to legislate for it.

160 See Taggart, above n 18, 342. Poumako, above n 24, is an example of such harder-edged dialogue - and one that resulted ultimately in legislative reform. 
